Article

\title{
The Vlaams Belang: A Mass Party of the 21st Century
}

\author{
Judith Sijstermans
}

Department of Political Science and International Studies, University of Birmingham, UK; E-Mail: j.sijstermans@bham.ac.uk

Submitted: 26 May 2021 | Accepted: 11 August 2021 | Published: 24 November 2021

\begin{abstract}
Throughout its 40-year history, the Vlaams Belang (VB, Flemish Interest) has established itself as an important player within the Belgian party system, albeit with significant electoral fluctuations. In 2019, it became the second largest party in Flanders. The party developed and maintained a mass-party organisation by investing significantly in local party branches and in a rigid vertically articulated structure. It relies heavily on social media, particularly Facebook, to communicate to supporters beyond the more limited group of party members. Using both modern and traditional tools, VB representatives aim to create communities of supporters bonded to the party, facilitating dissemination of the party's messages. Despite this investment in a grassroots organisation, the VB's decision-making remains highly centralised. Social media and local branches allow informal consideration of members' views, but the party has not created significant mechanisms for internal democracy. While it is often claimed that political parties have moved away from the "mass-party" model, this article demonstrates that the VB still maintains characteristics of the mass party, albeit with a modern twist. New social media tools facilitate attempts to foster communities and disseminate party messages among a wider group of supporters, both formal members and more informal sympathisers.
\end{abstract}

\section{Keywords}

mass parties; party membership; political communication; populism; Vlaams Belang

\section{Issue}

This article is part of the issue "Right-Wing Populist Party Organisation Across Europe: The Survival of the Mass-Party?" edited by Daniele Albertazzi (University of Surrey, UK) and Stijn van Kessel (Queen Mary University of London, UK).

(C) 2021 by the author; licensee Cogitatio (Lisbon, Portugal). This article is licensed under a Creative Commons Attribution 4.0 International License (CC BY).

\section{Introduction}

The time is ripe to re-examine the organisational structures of the Vlaams Belang (VB, Flemish Interest). The party made a comeback in the October 2018 municipal elections and came second place in the May 2019 European, federal, and Flemish elections. This article provides an update to previous work on the VB's organisational evolution (Art, 2008; Swyngedouw \& Van Craen, 2002; Van Haute \& Pauwels, 2016). Furthermore, I argue that the contemporary VB displays key organisational elements of the mass-party model. The party also enthusiastically adopts social media tools to remain connected to the party's grassroots, modernising traditional massparty structures.

As discussed in the introduction to this thematic issue, the mass-party model is characterised by a large, active membership that keeps the party rooted on the ground (Albertazzi \& McDonnell, 2015). The party cre- ates closed communities of activists that develop collective identities (Panebianco, 1988). These communities allow the party to mobilise voters and activists and can facilitate the spread of information through party membership (Katz \& Mair, 1995, p. 18).

The VB's organisational structures follow this model and display these characteristics. In particular, the VB invests in growing locally-rooted organisational structures and seeks to connect with party supporters on and offline. Strong links to the grassroots allow the party leadership to create a community of party supporters who campaign on the party's behalf. Through social media platforms, the VB speaks to a broad community of party supporters, not only formal members. While the party's formal membership numbers remain modest, the VB's investment in its wider grassroots base remains crucial to its political strategy.

In the first section of this article, I introduce the VB as a party. Then I review the characteristics of the 
mass-party model and note how these characteristics might be updated in light of modern technology and means of communication. In the third section of this article, I describe how the VB fits the mass-party model based on its organisational structures and outreach to members and supporters. In the fourth section, I consider whether those members and supporters have influence in the party. To do so, I explore the level of party centralisation and intra-party democracy, concluding that, while the VB displays many characteristics of the mass party, party members are neither formally nor informally empowered within the party's decisionmaking processes.

This article is based on an analysis of 32 interviews with party representatives at supranational, national, and local level. I also draw on secondary literature and party documents, particularly the party's statutes and its 2019 manifesto, to triangulate findings. Interviews were conducted in 2019 and 2020, both in person and using video conferencing platforms, due to the emergence of the Covid-19 pandemic. Interviewees' roles and regions are detailed in the Supplementary File. Of the 32 representatives interviewed, 14 were national or supranational parliamentarians. Interviewees played both institutional roles in political institutions, as local councillors or parliamentarians, and party roles, as members of the VB's governing boards at branch, regional, or national level. Interviews were conducted across three areas of Flanders (West Flanders, East Flanders, and Antwerp) in which the VB achieves various levels of electoral success. Within the first two areas, representatives from urban areas (Bruges and Ghent respectively) and smaller towns were interviewed.

\section{The Evolution of the Vlaams Belang}

The VB is a continuation of the Vlaams Blok. The party's name was changed in 2004, when a Belgian court ruled associations related to the party to be in breach of $a$ racism law. Despite this change in name, the $V B$ and Vlaams Blok are functionally equivalent: Few changes were made in response to the ruling, beyond a symbolic moderation of policies (Erk, 2005). The Vlaams Blok formed in 1978 as an electoral cartel between the VNP and the VVP, two parties formed due to dissatisfaction with the Volksunie's stance on state reform. These two parts ultimately merged into one after the elections of 1978. The Vlaams Blok struggled in its early years, but it maintained an MP in its traditional electoral stronghold of Antwerp.

After 1987, the party consistently won seats, albeit with a sharp downturn in 2010 and 2014. The party has been blocked from entering government by a strong cordon sanitaire, agreed from 1989 onwards between all other Belgian parties to rule out coalitions with the VB. The party managed to continue its growth, with a significant peak in the 2004 Flemish parliament elections. However, this peak was followed by subsequent decline until the 2018 local elections showed a resurgence of the party's popularity. Figure 1 illustrates the VB's recent electoral fluctuations in Flemish parliamentary elections; similar patterns were followed in Belgian federal and local elections. The party's electoral decline after 2004 led to frequent leadership turnover in 2008 (Bruno Valkeniers), 2012 (Gerolf Annemans), and 2014 (Tom van Grieken).

In 2014, Tom van Grieken, at the age of 28 , was elected as Belgium's youngest-ever party leader at the time. The party's website notes that 2014 was the year of "rejuvenation and renewal." In the wake of its 2019 electoral success and other Belgian parties' struggles to form a coalition, the VB announced the "Mission 2024" campaign that aimed to make it the largest party in the next Flemish elections. This, they argued, would make the cordon sanitaire untenable and give the VB the right to lead the government-formation process (Vlaams Belang, 2019a).

Flemish autonomy was initially most central to the VB's policy platform, but the party's ideology has shifted

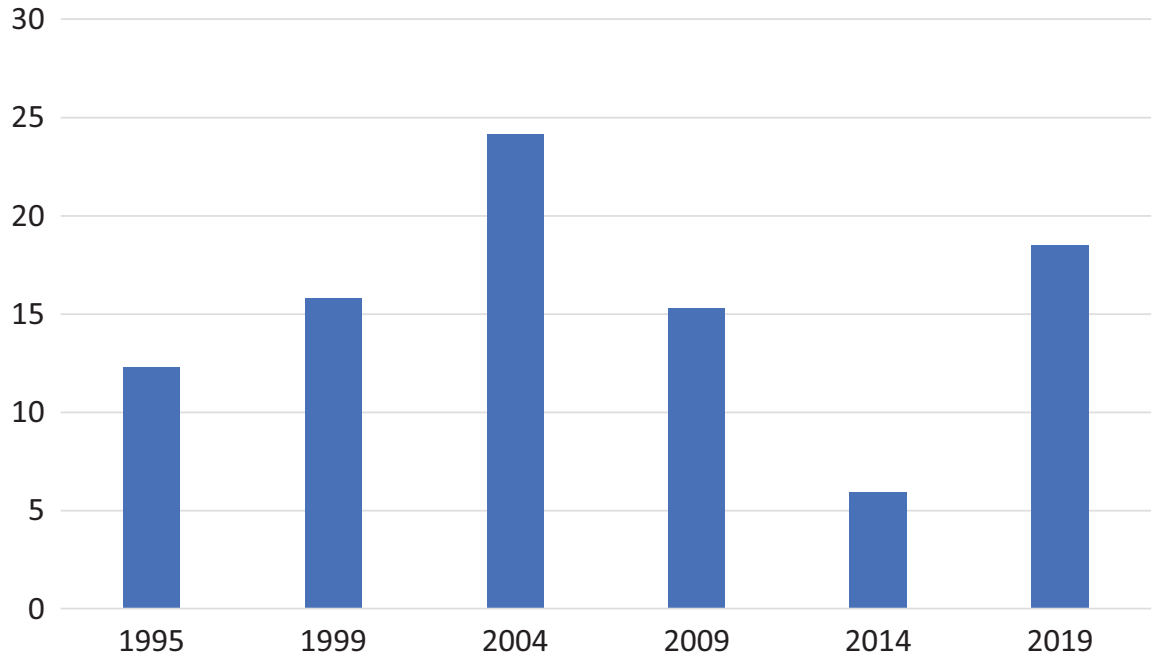

Figure 1. VB vote share over time in Flemish elections (1995-2019). 
towards nativist stances over time. In the 1980s, a period called "Operation Rejuvenation" initiated by party founder and leader Karel Dillen included popular new leaders Gerolf Annemans and Filip Dewinter and shifted the party platform towards opposition to immigration (Van Haute \& Pauwels, 2016, p. 51). In the party's 2019 manifesto and magazines leading up to the 2019 election, nativism remained the dominant theme. Nativist statements were included throughout other policy areas such as economic and welfare policies, whereas claims for more Flemish autonomy were more contained.

The VB's socio-economic policies retain elements of small government and low taxation but have begun to focus on providing social security for "deserving" Flemish citizens (Coffé, 2008; Fenger, 2018). The 2019 manifesto promoted limiting access to social security based on people's length of stay and work performance (Vlaams Belang, 2019b, pp. 60-61). The emphasis on deservingness criteria, such as identity and reciprocity, allows the VB to forefront the populist "us" versus "them" rhetoric through their economic policies (Van Oorschot, 2000).

Recently, the VB has moderated its discourse. Lucardie et al. (2016) described the attempt to "detoxify" the party and noted the shift in imagery from boxing gloves (associated with a campaign and political style typified by Dewinter) to images of families and children. The party has distanced itself from members' controversial, more hard-line behaviour (for example Dewinter's visit to Golden Dawn in Greece; see "Vlaams Belang supremos," 2016). However, as youth leader in 2012, Van Grieken himself took part in a controversial action at a school barbecue, protesting halal meat ("Vlaams Belang voert actie," 2012). Moderation is predominantly a change in style rather than in core ideology.

Given the VB's push to break through Belgium's 30-year cordon sanitaire and its recent electoral successes, this is a useful time to reconsider how the party organises itself and relates to its grassroots, and how this grassroots base fits into the party's strategy. In the following section, I consider how the mass-party model can help us understand the modern VB.

\section{Conceptualising the Modern Mass Party}

This thematic issue starts from the fundamental claim that the mass-party model persists, despite the increasingly close relationship between the state and political parties which led scholars to develop the cartel party model (Katz \& Mair, 1995). An analysis of party cartelisation in Belgium and Italy found that Flemish parties were moderately cartelised, more so than Belgian Francophone or Italian parties. However, the VB resisted cartelisation (Sandri \& Pauwels, 2010).

The mass-party model persists in some right-wing populist parties. Scholars have argued that these parties may challenge the cartelisation of party politics due to their claims to represent the "ordinary" citizen and challenge the "cosy arrangements" between the party and the state (Van Biezen, 2014, p. 181). Heinisch and Mazzoleni (2016, p. 241) concluded that many right-wing populist parties adopt "a mass party related organisation" with a focus on locally rooted organisational structures and building a "grassroots following." Three key characteristics of mass-party organisations should be emphasised: (1) the drive to recruit a large activist membership; (2) rootedness through local activities and structures; and (3) preserving "collective identities through ideology."

In this article, I specifically explore how massparty structures have been adapted through the use of modern digital tools. The effect of new technologies (social media, online communications, campaigning apps, among others) on political party organisations has been the subject of recent scholarly discussion with a focus on how they affect campaigns and party membership (Dommett et al., 2021; Kefford, 2018; McSwiney, 2020). Gerbaudo (2018) developed the concept of the "digital party" and Margetts (2006) explored the "cyber party." These types of party are "profoundly" digital; online organising and communications are inherent and fundamental to them. However, many parties use these technologies within traditional, established organisational structures. The VB is one such party.

Digital tools affect one key element of the mass party: party membership. Members are crucial to the mass party since they provide political resources and ideas and better relationships with voters. The cartel party, on the other hand, becomes less dependent on members due to increased state support (Gauja, 2015, pp. 234-235; Katz \& Mair, 2009). Across Europe, the size of party membership in relation to the total electorate has shrunk from approximately $15 \%$ to $4.7 \%$ in 2008 (Van Biezen et al., 2012). In response to this shift and newly available digital tools, parties developed new forms of engagement with citizens and created new forms of partisan affiliation, such as supporter or friendship networks (Gauja, 2015; Scarrow, 2014, p. 3). Online partisan affiliation has diverse faces, from "friend" to "audience" to "digital activist," and some online followers, such as the "digital activist," are also often formal members (Gibson et al., 2017).

Relationships between parties and supporters may be mediated less by formal membership cards or contacts and more through social media networking. However, these developments are not antithetical to the mass-party model. Rather, in a modern mass party, the "masses" of a party may be both formal members and more informal supporters, and parties may make use of new, increasingly important digital tools of communication alongside a traditional "ground game."

\section{The Vlaams Belang and the Modern Mass-Party Organisation}

The VB seeks to have an active and large grassroots base (formal members and informal supporters), organised through clearly articulated local, regional, and provincial 
executive boards. Local branches play a key role in organising social and political activities which maintain regular connection with active supporters and recruit new supporters. Recruitment occurs through a mixture of digital and traditional tools. Party representatives' motivations behind maintaining these structures highlight the importance of party communities in spreading party information to voters.

Within the mass-party structure, the party has invested in social media tools. Social media support recruitment by helping to identify informally affiliated supporters and engage them in local activities. The move towards social media forms of organising has also engendered more ambivalence towards the importance of the formal party member. Party activities and communications seek to be open to both formal members and informal supporters.

\subsection{Organisational Structures}

The VB has a high degree of organisation ("the extent of regularised procedures for mobilising and coordinating the efforts of party supporters") which allows the party to maintain close links to its grassroots base (Janda, 1970 , p. 106). Vertical organisational linkages, which structure the relationships between the grassroots and elites, are one of the key characteristics of the mass party (Panebianco, 1988, p. 264). In this section, I illustrate how the VB follows a mass-party model by considering the party's locally rooted organisational structures.

The party is characterised by a series of formal executive bodies, at various geographical levels: local branches, regions, provinces, and a national-level party council. As described in the party statutes, these levels are linked through delegates from lower levels to upper levelsi.e., local branch members are selected to represent the branch at regional level; representatives from the region are delegated to the provincial executive; and members of regional and provincial boards represent their areas at the party's national council. A key function of delegated members is to transmit information from the national level to the local branches (Interview 1). They also provide direct linkage between the local branch and the national party; local respondents often discussed feeling that they had a "direct line" to the party's Brussels headquarters.

The VB has approximately 160 branches across Flanders' 300 (previously 308) municipalities. This is fewer than the largest Flemish party, the N-VA, which in 2012 had 306 branches (Beyens et al., 2017, p. 396). The third-largest party in Flanders, the CD\&V, lists 288 branches on its website. While the VB falls behind in absolute number of branches, the party has targeted increasing this number as part of its current growth strategy. The investment in branches is what leader Van Grieken calls "local anchoring" and is part of the party's plan for gaining power nationally ("Horizon 2024," 2020).
Since the electoral successes of May 2019, VB representatives report newfound interest in starting or rejuvenating branches (Interview 4). The extent of this rejuvenation or increase in branches is not possible to measure concretely. However, the party's funding to support party branches is clearer. The party has set up a system of mentorship between national representatives and new branches in their area in which parliamentarians act as "godparents" for new branches. Since 2019, the party has allowed branches to retain all their local area's membership fees rather than asking them to share $30 \%$ of membership fees with the national level, as was previously mandated. The party recently expanded its staff from 30 to 100 . This included newly hired provincial staff members that provide support to existing and prospective branches, for both in-person and digital activities (Interviews 4, 30, 31).

The VB's local anchoring strategy and delegated vertical strategy is consistent with the mass-party model, which entails organising a broad group of grassroots supporters and developing a "locally rooted, complex and durable organisation" (Heinisch \& Mazzoleni, 2016, p. 241).

\subsection{Membership and Member Recruitment}

Local anchoring requires having active members to sit on local executive boards, organise activities, run on local electoral lists, and campaign across Flanders. The party seeks to identify new members and to engage existing members. Identifying voters is also the focus of local party organising, and this is set to become more important as the legal requirement to vote has been lifted for local elections in Flanders. A key parliamentarian and member of the party's executive structures noted that the party would engage in more voter-mobilisation activities as a result of this change (Interview 32). In this section, I explore the party's efforts to recruit supporters/members and argue that this core feature of the mass party remains a crucial element of the party's strategy. I then consider, drawing on previous literature on the evolving nature of party membership, how informal forms of partisan support are incorporated in the VB.

Traditional mainstream parties (socialists, Christian Democrats, and liberals) in Flanders and Wallonia saw their membership numbers peak by 1991 and decrease throughout the 1990s and early 2000s (Van Haute et al., 2013). The VB grew its membership through the 1990s and early 2000s, alongside Flemish nationalist competitors the N-VA and radical left PvdA/PtB. However, as can be seen in Table 1, the party's current membership has fallen below its peak in the mid-2000s. Representatives suggested that this membership stagnation was part of a wider trend of disengagement from political party membership. However, decreases in party membership corresponded with electoral defeat as the party underwent internal turmoil, leadership turnover, and defections 
to the N-VA and short-lived populist competitor LDD (Pauwels, 2011; Van Haute \& Pauwels, 2016, p. 54).

Table 1. Membership numbers over time (1984-2018).

\begin{tabular}{lc}
\hline Year & Members \\
\hline 1984 & 3,269 \\
1988 & 2,485 \\
1992 & 4,682 \\
1996 & 10,039 \\
2000 & 17,167 \\
2003 & 16,860 \\
2007 & 25,000 \\
2009 & 22,500 \\
2012 & 17,063 \\
2018 & 18,153 \\
2021 & 22,194 \\
\hline
\end{tabular}

Notes: Data until 2000 was taken from Swyngedouw and Van Craen (2002, p. 15); data from 2003-2009 was taken from Van Haute et al. (2013); data for 2018 was taken from Vlaeminck (2018); data for 2021 was taken from "Vlaams Belang ziet ledenaantal stevig stijgen" (2021).

Recruitment of new members and member engagement occurs both through local branch activities and through social media. One staffer estimated that about half of members join through local branches and half through online tools (Interview 30). Most respondents noted that online and in-person contacts were complementary. Social activities organised locally, such as new year's receptions, or political talks by big names such as Van Grieken or Dewinter, are open to non-members and provide recruitment opportunities (Interviews 10, 14). Prospective members can also request a "trial membership" for three months, during which time a local representative or branch member will visit the trial member's home.

One party staff member working closely with local branches explained: "In terms of the local... personal contact is still the best. For example, what's being said to us, also in relation to the 2024 campaigns, is that we have to concentrate on house-to-house visits." In Ninove, where the party achieved $40 \%$ of the vote in the last local elections, the local VB organisation does extensive house-tohouse canvassing to seek out supporters (Interview 18). This is now being tried in other municipalities such as Brasschaat (near Antwerp) and Ghent (Interviews 6, 8).

House-to-house recruitment is supported by digital tools. The party's recent face mask campaign provides an example of this. On social media, the party heavily advertised its offer of free VB face masks for those who "registered as VB voters." These contact details were collated, and the party created a mobile app to facilitate visits to these contacts by offering locations of houses and walking directions between them. Figure 2 shows one of the graphics used on Facebook for this campaign. Recruitment required both capital investment into social and digital media and party activists' labour. This echoes successful political movements elsewhere, where social media campaigning is paired with labour-intensive supporter mobilisation (Kefford, 2018, p. 659). Party elites referred to Donald Trump's campaign social media and rallies as an inspiration (Interviews 14, 30, 32).

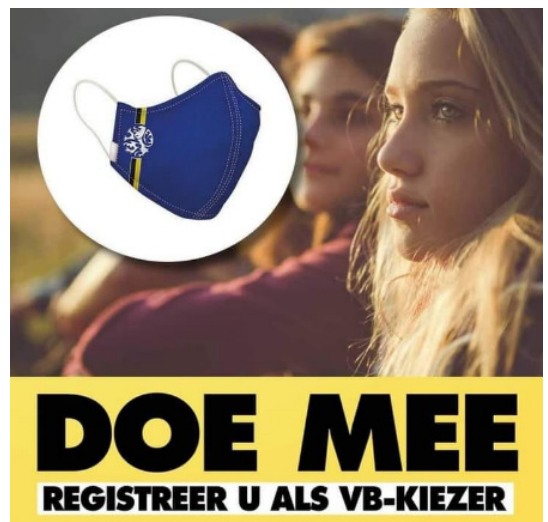

Figure 2. VB Facebook graphic advertising free face masks. Source: Vlaams Belang Geraardsbergen (2020).

In terms of online engagement, respondents noted that new party members also regularly join "spontaneously" through the party's national website (Interviews 6, 22, 23). The VB spent more than any other party on online advertising during the May 2019 election, and this investment has continued after the campaign (Vandeputte \& De Smedt, 2019). Maly (2020) analyses the party's social media posts and highlights that the VB used both ads and provocative "organic" viral content to grow its following over time.

The party has 611,000 Facebook likes as of August 2021 , just under 200,000 more than its closest competitor, the N-VA. This does not necessarily indicate the size of absolute support for the $\mathrm{VB}$, as the number will include non-VB voters and some fake "bot" accounts. However, the Facebook page provides a way for the party to keep in touch with its grassroots support and often provides access to those in the party's "audience" or "friends" group alongside party members. One representative explained: "Not everyone [who follows the party on Facebook] is, of course, a member, maybe not everyone supports all of what we do, but they do follow us" (Interview 6). A DEMOS survey in 2011, which included the VB, found that $67 \%$ of Facebook followers voted for the party at the most recent national election (Bartlett et al., 2011). The party's Facebook thus brings together a significantly wider pool of the party's supporters than formal membership.

Social media allow the party to identify and recruit some non-member sympathisers to formal membership. Dewinter, in an interview, noted: "Through social media we get a lot of contact details from people who have sympathy for the party but then also aren't members. If you can engage those people and recruit them and create a bigger engagement, that's important." Another MP explained: 
Specialised staff members in Brussels post Facebook advertisements....For example, if there are problems with an asylum centre in Koksijde then Facebook posts or advertisements are sent to the people of Koksijde and then we get responses. Staff members in West Flanders collect those, with addresses, and that's how you get addresses and make contact. (Interview 14)

The VB invests both in membership recruitment and more diffuse engagement of its informal supporter base online. Party elites emphasise that the audience for its online communications is not only members but a more diffuse group of supporters. The party's campaign asking these followers to "register as VB voters," discussed above, shows how the VB is seeking to capitalise on new forms of partisan affiliation. Scarrow (2014) has emphasised that affiliation with political parties takes many forms. She identifies relationships with members using electronic media as the most common new form of party affiliation. Parties may offer "cyber membership" or engage with social media "followers" or an online "news audience." No form of affiliation is necessarily more important than the other and each provides parties with different opportunities. Social media followers, for example, may receive significant amounts of information from the party and participate in two-way exchange (Scarrow, 2014, pp. 33-35).

Registration as a voter requires no monetary commitment, unlike party membership, but benefits the party by providing clear voter identification and contact details. Non-member sympathisers are also encouraged through social media to become involved in local party life. All party events are advertised on Facebook, and local events are almost always open to non-members. Like registering as a voter, an open approach to party events and communications offers a "low level" way of becoming involved in the party (Interview 10). Social media support is seen as a corrective to the overall societal trend of falling party membership numbers. A Flemish MP with key executive roles in the party explained: "I think that membership [of all organisations] is declining... but that doesn't take away from the fact that they support usfor example, on Facebook or social media" (Interview 4).

The VB thus displays key characteristics of the mass party, investing in and seeking to expand its supporter base. However, the party adopts a more modern and flexible concept of the mass party. In the following section, I show that the motivations for investing in an activist base echo the motivations of the mass party: creating a sense of collective identity and mobilising the grassroots to reach voters.

\subsection{Motivations for the Mass-Party Structure}

In the mass party, identity was a crucial driver of party membership and members were "actively recruited and encapsulated" within close communities (Katz \& Mair,
1995 , p. 18). When exploring the motivations for the VB's investment in local activities and members, elites pointed to the creation of community and the mobilisation of that community to reach out to voters.

The VB invests in social activities at a local level, such as yearly festive meals, barbecues, wine and cheese evenings, brunches, and book launches. Local activities create small, close communities. The purpose of activities, one provincial councillor explains, is to bring people together in a pleasant and sociable way (Interview 20). Dewinter explained: "Cultivating camaraderie is important. It has to be a friendship group. You have to bind them to each other." Social media also play a part in developing community. The VB's social media coordinator and MP Bart Claes explained to De Morgen: "In 2014, VB was nowhere to be found. Not in the media, nor in people's minds. That is why we have put a lot of effort into building a community, a digital community" (Kelepouris, 2019).

The sense of community in the VB is not rooted in being part of the same union or church, as may have traditionally been the case for the mass party. The community feeling is instead rooted in members' feeling of exclusion from mainstream Belgian politics. The cordon sanitaire, one West Flemish provincial councillor explained, "ensures that we have the bond of 'us' versus the rest....All the attacks that we receive ensure that we have a very high 'Robin Hood' feeling" (Interview 16). Friendships are more meaningful because "you are in the same boat; you don't have anyone else" (Interview 13). As such, the VB as a modern mass party builds upon socially integrated communities.

These communities spread party propaganda to voters. One MP and local councillor explained: "The word-ofmouth effect is still very important. If you have friends who are Vlaams Belangers, and who do well and are engaged, then you are very quickly inclined to come along or maybe to vote for our party" (Interview 13). Activists also provide publicity by speaking with friends, delivering leaflets, putting up posters, and distributing materials at local events (Interview 6). One local staff member explained: "You can say that you do everything online now, but you still need to put up posters, deliver leaflets, and there it's very good to trigger those active members, to hold them to you" (Interview 22).

Information sharing also occurs online. One MP elaborated: "Over the last few years we have seen that people are informed much easier through social media" (Interview 5). The nature of social media (retweeting or sharing on Facebook) allows the central party to control local messaging, because central messages can easily be replicated (Interview 13). Strong digital communities ensure that the party's information gets shared through supporters as well as advertisements. The party has focused on hiring strong social media staff and has developed party messages that are "clearly constructed for online engagement" and "ready-made for uptake" (Maly, 2020, p. 9). 
The VB's emphasis on informing supporters directly rather than through the mass media could be interpreted as a sign of its adoption of the mass-party model. The traditional mass party used "a party press and other party-related channels of communication [to make up] for what it lacked in access to the commercial press" (Katz \& Mair, 1995, p. 10). De Jonge (2019) notes that Flemish media have generally been more open to the VB than media counterparts in Wallonia. However, respondents perceived that the party and Van Grieken received less attention than mainstream parties in Flemish media. Increasingly throughout 2020 and 2021, they made claims of "censorship" on social media platforms. Suspensions or threats of suspension by these platforms against Van Grieken were widely publicised by the party. VB representatives argued that their use of social media and direct communication style were necessitated by what they perceived as a lack of access to the traditional mass media. While they may have access to the mass media, it is clear that the party uses narratives of exclusion to drive community building and promote information sharing through these party communities.

The VB remains committed to the fundamental motivations underpinning the mass-party structure, using an activist base and sense of community between members to spread information. In the next section I show that, despite investment in a mass-party structure, the grassroots of the party do not play a significant role in VB decision-making processes.

\section{Centralisation of Power and Internal Democracy}

Scholars have documented how political parties introduced new forms of participation to incentivise party membership (Faucher, 2015; Gauja, 2015; Poguntke et al., 2016). A review of recent party research suggests that intra-party democracy is part of parties' "efforts to repair the broken links with the electorate and party members and activists," although evaluations suggest that the effect may not have actually revitalised political parties (Borz \& Janda, 2020; Ignazi, 2020). Digital media, which can facilitate intra-party democracy, has also been seen as an opportunity to open parties up to rejuvenation from below. In some cases, these new ways of communicating within the party mean that "citizens are breathing new life into the party form, remaking parties in their own changed participatory image" (Chadwick \& Stromer-Galley, 2016, p. 285).

However, while social media provide new opportunities for two-way communication, members' influence on party decision-making is not necessarily increased. While the VB invests in growing a grassroots base and in social media, it maintains highly centralised decision-making processes. The VB's enthusiastic adoption of social media and informal types of party affiliation have not altered members' power in the party. The party invests in communicating central decisions to supporters, but these supporters are not empowered to contribute to party decision-making.

\subsection{Highly Centralised Decision-Making}

As noted previously, the VB has a vertically articulated series of executive boards from which members are delegated upwards. Statutorily, the VB's highest organisational body is the Party Council. However, in this section I show that the party leader and executive (selected by the leader) still make most of the important decisions in the party. They wield influence on policy, strategy, discipline, and candidate selection. Given this party centralisation, ordinary party members, or those only active in local politics, have very little influence on party decisionmaking. One MP noted: "Our Party Council was once powerful. It has even rejected proposals from the Party Executive, but that was some time ago now. It can happen but it's not self-evident" (Interview 11). A local councillor also emphasised: "The Party Executive is omnipotent; it is the daily leadership" (Interview 7).

The party leader is responsible for the party's overall policy and political direction and disciplinary matters. The Party Executive comprises twelve to fifteen members: leaders of the parliamentary groups, deputy leader(s), party treasurer, chairman of the Party Council, and additional members selected by the leader. The leader appoints all these positions, further consolidating their power (Wauters \& Pittoors, 2019). The Executive determines urgent political questions and daily management of the party. This small group of party elites is instrumental in the party's policy, campaign, and disciplinary decisions.

However, policymaking requires a diverse range of contributors, given the range of topics covered. The party's manifesto is developed by a working group comprised of party and parliamentary staff, elected members, and members of the Party Executive. The manifesto then undergoes a process of revisions by the Party Council. The Party Executive's "day-to-day" role gives it the power to make short-term policy and strategy decisions which are rarely or never challenged by the Party Council (Interview 21). Party staff and the Executive are also the most important actors in campaigns. During campaigns, the party provides leaflet templates and coordinates printing centrally (Interview 1). Party branding and campaign strategies are thus centralised. Social media also "ensures that a small group centrally sends a message, and it then gets spread" (Interview 14).

Another way to shape the behaviour of its local members on social media is through social media training and guidance provided by party staffers. However, controversial statements are sometimes made by party members and raised with the party, often by the media. In these cases, and other cases of internal conflict, the party leader and the Executive are also crucial in conducting disciplinary procedures. Each level of the party (local, regional, provincial) can mediate an emerging 
disciplinary issue. If this does not generate a resolution, the party leader and the Executive get involved directly and can sanction members. According to the party's statutes, all sections of the party are responsible for reporting "facts that jeopardize the proper functioning or reputation of the party" to the party leader (VB statutes [party statutes are not publicly available but were provided to the author by the party]). Disciplinary procedures are thus favourable to the interests of the party rather than those of the complainant.

Finally, candidate selection is centred on the wishes of the Party Executive. Multiple interview respondents described the process as "complicated," and selection procedures are not clearly set out in the party statutes. Respondents explained that the Party Executive, in discussion with provincial executive members, determines list leaders and electable list places. The list leader and provincial executive then fill out the rest of the candidates. All lists are ratified by the Party Council. Across the decision-making procedures, we can see that the Party Council's role is one of ratification rather than decision. This highlights the way that the VB's leader and the Executive, supported by staff, maintain central control, and make most decisions directly.

The nature of the Belgian system allows for some internal "balance of power" between elite members. Belgium's divided legislative institutions ensure that no one individual is in complete control. In Belgium, the role of party leader has traditionally not overlapped with the role of government or parliamentary leader. Tom van Grieken is not the leader of the VB group in the Belgian Chamber of Representatives, for example. By decentralising power internally, representatives can build a profile locally. Several representatives noted how that, as group leaders in city councils and parliamentarians, they could act as the figurehead in their specific city.

The VB also distributes power internally by "matching up key party officials with political issue areas" (Van Haute \& Pauwels, 2016, p. 67). Under Van Grieken's leadership, significant staffing resource has been focused on the party's parliamentary staff. In a process of professionalisation, the party's parliamentarians have thus begun to specialise in different policy areas and to develop more substantive knowledge (Interviews 9, 32). Rhetorically, some leaders like Dewinter and Dries van Langenhove take more "hard-line" stances while others use more moderate language. Although a balance is found between elites, those who take the lead in decision-making on policy, campaigns and discipline are still a relatively small group of people.

\subsection{Limited Internal Democracy}

Including members in decision-making can occur through assembly (exchange of arguments in party organs, inclusiveness of forums) and plebiscitary methods (on a one member, one vote basis; see Poguntke et al., 2016). In the VB, the only case in which members vote is for leadership selection. To elect a VB leader, an internal vote occurs within the Party Council. Once this process is completed, the Party Council puts forth one candidate to party members, who convene at a national congress. All individuals who have been a member for at least one year can cast their ballot to support (or not) that candidate. The only contested leadership selection at the stage of the Party Council vote was during the election of Gerolf Annemans (elected 2012). All other leaders were elected unopposed. In fact, until 2008, party leaders were not elected at all. After almost 20 years of leadership, founder Karel Dillen appointed his successor, Frank Van Hecke. The lack of competition and newness of this procedure means it is not robust and is generally seen as a formality by representatives.

In terms of the exchange of ideas in assemblies, the VB has numerous levels of executive boards. Ordinary members can get involved by joining local executive boards and becoming delegates to regional, provincial, and national bodies. There is a low barrier to entry, with most interested members accepted onto local executive boards (which seem to have no limit on membership numbers). However, regional and provincial levels are not empowered to make many decisions. One MP explained: "We have provincial structures, but those rarely come together, and regional structures, but they are more about passing on information top to bottom" (Interview 18). In fact, the regional level is likely to be removed after a reorganisation of Flemish electoral boundaries.

Social media provide another way for ordinary members to provide input. The VB can test policies, using reactions as a sounding board. One Flemish MP explained:

We have a team, in the Vlaams Belang that is concerned with social media and mostly with the reactions we get. We take those reactions into account, and it's not always members who [respond online] but also normal citizens, who are not members. (Interview 9)

This substantiates the expansion of the concept of a grassroots base in the VB, as the party considers input not only from members but from a wider group of online supporters. However, responding to supporters' concerns on social media should not be conflated with internal party democracy. While eliciting opinions on social media allows a party to gauge supporters' positions and presents an image of two-way exchange with supporters, there is no obligatory inclusion or deliberation in this process.

The concept of intra-party democracy is often fuzzy. Intra-party democracy could include plebiscitary and assembly methods, and various elements of democracy, such as representation, responsiveness, and competition (Borz \& Janda, 2020). The VB has very limited voting rights for party members. Furthermore, the party's most important assembly for exchange of ideas, the Party 
Council, tends to take a ratifying rather than deliberative function. Given these limitations, despite an interest in fostering a wide supporter base, it is the Party Executive and leader that make key policy and strategy decisions.

\section{Conclusion}

The VB maintains a mass-party model which includes a vertically delegated and strongly articulated set of local, regional and provincial bodies. The party's leader Tom van Grieken has emphasised the importance of local anchoring in branches, and party representatives at all levels emphasised the need for and existence of a sense of community between members. Local branches thus seek to bring existing members together and to recruit new members and activists. Local activities and social media can mobilise these party communities to disseminate information. In fact, the party's "Mission 2024" electoral strategy is highly reliant on mobilising and growing a grassroots base, highlighting the importance of the massparty model.

In this article, I have focused on the VB's investment in new technologies such as social media networks and digital campaign tools such as Facebook advertisements and mobile apps. Through these tools, the mass-party model can take on a more modern form. This modern form is typified by a more expansive understanding of parties' grassroots bases. While the VB seeks to build a formal membership, it also uses social media to identify more informal "friends" of the party. In the modern mass party, then, party affiliation is truly "multi-speed," as Scarrow (2014) argued. The masses that the VB seeks to identify, assemble, and influence do not all carry the party's formal membership card. Rather, some may simply be followers while others may seek affiliation by registering as voters or ordering party materials such as face masks. Regardless of which form of affiliation is chosen, the party seeks to communicate with these people and encourage a sense of collective identity. That collective identity is based not on traditional affiliations such as churches or unions, but rather in a feeling of exclusion from mainstream Belgian politics.

Although the party invests in growing its grassroots base, when it comes to internal decision-making, grassroots supporters are not empowered to make decisions. The party leader and the Executive have decisive roles in most aspects of party life. The party's ordinary members have limited input. While party representatives argue that consultation with party supporters occurs through feedback on social media and through local executives, this feedback is ultimately informal. As such, it cannot be conflated with internal party democracy.

The VB is a modern mass party that has enthusiastically adopted new technologies. These new technologies have facilitated the party's relationship with a wide grassroots supporter group. The VB is thus a useful case of a party which incorporates digital tools into traditional forms of political party organisation. Combining new technologies with local organising may rejuvenate the mass-party model which was thought by some (prematurely) to be an organisational model of the past.

\section{Acknowledgments}

The support of the Economic and Social Research Council (ESRC) is gratefully acknowledged (Grant Ref: ES/R011540/1). I acknowledge the helpful and constructive feedback of the anonymous reviewers and the editors. I also thank Dr Adrian Favero, Dr Niko Hatakka, and Dr Mattia Zulianello for their feedback and support.

\section{Conflict of Interests}

The author declares no conflict of interests.

\section{Supplementary Material}

Supplementary material for this article is available online in the format provided by the author (unedited).

\section{References}

Albertazzi, D., \& McDonnell, D. (2015). Populists in power. Routledge.

Art, D. (2008). The organizational origins of the contemporary radical right: The case of Belgium. Comparative Politics, 40(4), 421-440.

Bartlett, J., Birdwell, J., \& Littler, M. (2011). The new face of digital populism. Demos.

Beyens, S., Deschouwer, K., Van Haute, E., \& Verthé, T. (2017). Born again, or born anew: Assessing the newness of the Belgian New-Flemish Alliance (N-VA). Party Politics, 23(4), 389-399.

Borz, G., \& Janda, K. (2020). Contemporary trends in party organization: Revisiting intra-party democracy. Party Politics, 26(1), 3-8.

Chadwick, A., \& Stromer-Galley, J. (2016). Digital media, power, and democracy in parties and election campaigns: Party decline or party renewal? The International Journal of Press/Politics, 21(3), 283-293.

Coffé, H. (2008). (Small) Entrepreneurs first! Analysis of the economic discourse of the Vlaams Belang. Journal of Language and Politics, 7(1), 31-52.

de Jonge, L. (2019). The populist radical right and the media in the Benelux: Friend or foe? The International Journal of Press/Politics, 24(2), 189-209.

Dommett, K., Fitzpatrick, J., Mosca, L., \& Gerbaudo, P. (2021). Are digital parties the future of party organization? A symposium on the digital party: Political organisation and online democracy by Paolo Gerbaudo. Italian Political Science Review/Rivista Italiana di Scienza Politica, 51(1), 136-149.

Erk, J. (2005). From Vlaams Blok to Vlaams Belang: The Belgian far-right renames itself. West European Politics, 28(3), 493-502.

Faucher, F. (2015). New forms of political participation: 
Changing demands or changing opportunities to participate in political parties? Comparative European Politics, 13(4), 405-429.

Fenger, M. (2018). The social policy agendas of populist radical right parties in comparative perspective. Journal of International and Comparative Social Policy, 34(3), 188-209.

Gauja, A. (2015). The construction of party membership. European Journal of Political Research, 54(2), 232-248.

Gerbaudo, P. (2018). The digital party: Political organisation and online democracy. Pluto Press.

Gibson, R., Greffet, F., \& Cantijoch, M. (2017). Friend or foe? Digital technologies and the changing nature of party membership. Political Communication, 34(1), 89-111.

Heinisch, R., \& Mazzoleni, O. (Eds.). (2016). Understanding populist party organisation. Palgrave Macmillan.

Horizon 2024: Hoe Vlaams Belang Vlaanderen wil veroveren [Horizon 2024: How Vlaams Belang wants to conquer Flanders]. (2020, February 25). Knack. https://www.knack.be/nieuws/belgie/horizon-2024 -hoe-vlaams-belang-vlaanderen-wil-veroveren/ article-normal-1568817.html?cookie_check= 1589186850

Ignazi, P. (2020). The four knights of intra-party democracy: A rescue for party delegitimation. Party Politics, 26(1), 9-20.

Janda, K. (1970). A conceptual framework for the comparative analysis of political parties. SAGE.

Katz, R. S., \& Mair, P. (1995). Changing models of party organization and party democracy: The emergence of the cartel party. Party Politics, 1(1), 5-28.

Katz, R. S., \& Mair, P. (2009). The cartel party thesis: A restatement. Perspectives on Politics, 7(4), 753-766.

Kefford, G. (2018). Digital media, ground wars and party organisation: Does Stratarchy explain how parties organise election campaigns? Parliamentary Affairs, 71(3), 656-673.

Kelepouris, S. (2019, May 28). Hoe Vlaams Belang via Facebook de verkiezingen won [How the Vlaams Belang won the elections]. De Morgen. https:// www.demorgen.be/politiek/hoe-vlaams-belang-viafacebook-de-verkiezingen-won $\sim$ b2958a3f

Lucardie, P., Akkerman, T., \& Pauwels, T. (2016). It is still a long way from Madou Square to Law Street: The evolution of the Vlaams Belang. In T. Akkerman, S. de Lange, \& M. Rooduijn (Eds.), Radical right-wing populist parties in Western Europe: Into the mainstream? (pp. 226-242). Routledge.

Maly, I. (2020). Flemish Interest in an attention-based hybrid media system (Tilburg Papers in Culture Studies No. 240). Tilburg University. https://research. tilburguniversity.edu/en/publications/flemishinterest-in-an-attention-based-hybrid-media-system Margetts, H. (2006). The cyber party. In R. S. Katz \& W. Crotty (Eds.), Handbook of party politics (pp.
528-535). SAGE.

McSwiney, J. (2020). Social networks and digital organisation: Far right parties at the 2019 Australian federal election. Information, Communication \& Society, 24(10), 1401-1418.

Panebianco, A. (1988). Political parties: Organisation and power. Cambridge University Press.

Pauwels, T. (2011). Explaining the strange decline of the populist radical right Vlaams Belang in Belgium: The impact of permanent opposition. Acta Politica, 46(1), 60-82.

Poguntke, T., Scarrow, S. E., Webb, P. D., Allern, E. H., Aylott, N., Van Biezen, I., Calossi, E., Costa Lobo, M., Cross, W. P., Deschouwer, K., Enyedi, Z., Fabre, E., Farrell, D., Guaja, A., Pizzimenti, E., Kopecky, P., Koole, R., Muller, W. C., Kosiara-Pederson, K., . . . Verge, T. (2016). Party rules, party resources and the politics of parliamentary democracies: How parties organize in the 21st century. Party Politics, 22(6), 661-678.

Sandri, G., \& Pauwels, T. (2010). Party membership role and party cartelization in Belgium and Italy: Two faces of the same medal? Politics \& Policy, 38(6), 1237-1266.

Scarrow, S. (2014). Beyond party members: Changing approaches to partisan mobilization. Oxford University Press.

Swyngedouw, M., \& Van Craen, M. (2002). Het Vlaams Blok: Een Overzichtsstudie [The Vlaams Belang: An overview study]. Instituut voor Sociaal en Politiek Opinieonderzoek, Kathoieke Universiteit Leuven.

Van Biezen, I. (2014). The end of party democracy as we know it? A tribute to Peter Mair. Irish Political Studies, 29(2), 177-193.

Van Biezen, I., Mair, P., \& Poguntke, T. (2012). Going, going... gone? The decline of party membership in contemporary Europe. European Journal of Political Research, 51(1), 24-56.

Van Haute, E., \& Pauwels, T. (2016). The Vlaams Belang: Party organization and party dynamics. In R. Heinisch \& O. Mazzoleni (Eds.), Understanding populist party organisation (pp. 49-77). Palgrave Macmillan.

Van Haute, E., Amjahad, A., Borriello, A., Close, C., \& Sandri, G. (2013). Party members in a pillarised partitocracy. An empirical overview of party membership figures and profiles in Belgium. Acta Politica, 48(1), 68-91.

Van Oorschot, W. (2000). Who should get what, and why? On deservingness criteria and the conditionality of solidarity among the public. Policy \& Politics, 28(1), 33-48.

andeputte, B., \& De Smedt, P. (2019, November 15). Vlaams Belang gaf sinds maart al 1,2 miljoen euro uit aan advertenties op Facebook, veel meer dan de andere partijen [Vlaams Belang spent 1.2 million euro on Facebook advertisements since March, much more than other parties]. VRT. https://www. vrt.be/vrtnws/nl/2019/11/15/politieke-partijenblijven-campagne-voeren 
Vlaams Belang. (2019a, September 28). Missie 2024 [Mission 2024]. https://www.vlaamsbelang.org/missie2024

Vlaams Belang. (2019b). Eerst Onze Mensen: Verkiezingsprogramma 2019 [Our people first: Election programme 2019]. https://www.vlaamsbelang.org/ programma

Vlaams Belang Geraardsbergen. (2020, October 25). DOE MEE! Registreer $u$ als VB-kiezer en krijg van ons een gratis mondmasker opgestuurd via www.vlaamsbelang.org/doemee [TAKE PART! Register yourself as a VB-voter and get a free facemask sent to you via www.vlaamsbelang.org/doemee] [Facebook status update]. https://www.facebook. com/251314822084953/posts/doe-mee-registreeru-als-vb-kiezer-en-krijg-van-ons-een-gratismondmasker-opgest/774881656394931

Vlaams Belang supremos censured following Golden Dawn outing. (2016, November 21). VRT. https:// www.vrt.be/vrtnws/en/2016/11/21/vlaams_belang _supremoscensuredfollowinggoldendawnouting-12824252

Vlaams Belang voert actie tijdens 'halalbarbecue' [Vlaams Belang takes action during 'hallal-barbecue']. (2012, June 14). Knack. https://www.knack.be/ nieuws/belgie/vlaams-belang-voert-actie-tijdenshalalbarbecue/article-normal-58594.html

Vlaams Belang ziet ledenaantal stevig stijgen [Vlaams Belang sees membership numbers increase substantially]. (2021, June 18). HLN. https://www.hln. be/nieuws/vlaams-belang-ziet-ledenaantal-stevigstijgen a81ad01d

Vlaeminck, N. (2018, January 23). Ondanks hoeraberichten: Steeds minder partijleden [Despite celebratory messages: Still fewer party members]. VRT. https://www.vrt.be/vrtnws/nl/2018/01/23/ steeds-minder-politieke-partijleden

Wauters, B., \& Pittoors, G. (2019). Populist party leaders in Belgium: An analysis of VB and PVDA-PTB. Polish Political Science Review, 7(1), 1-23.

\section{About the Author}

Judith Sijstermans (PhD) is a research fellow at the University of Birmingham on the Survival of the Mass Party project, funded by the ESRC, where she focuses on the Flemish case of the Vlaams Belang. She has previously worked on territorial politics and completed her PhD at the University of Edinburgh. 